\title{
Physicochemical quality of and Escherichia coli resistance profiles in urban surface waters
}

\author{
I. Malagi ${ }^{a *}$ (D), S. C. Sampaio ${ }^{a}$ (D), F. G. S. Pinto ${ }^{b}$ (D), D. M. Rosa ${ }^{a}$ (D) and R. R. dos Reis ${ }^{a}$ \\ ${ }^{a}$ Laboratório de Pesquisa em Ciências Agroambientais, Universidade Estadual do Oeste do Paraná - UNIOESTE, \\ Rua Universitária, 2069, Jardim Universitário, CEP 85819-110, Cascavel, PR, Brasil \\ 'Programa de Pós-graduação em Conservação e Manejo de Recursos Naturais, Laboratório de Biotecnologia e \\ Microbiologia, Universidade Estadual do Oeste do Paraná - UNIOESTE, Rua Universitária, 2069, Jardim Universitário, \\ CEP 85819-110, Cascavel, PR, Brasil \\ *e-mail: ivairmalagi@gmail.com
}

Received: January 22, 2019 - Accepted: May 22, 2019 - Distributed: August 31, 2020

(With 3 figures)

\begin{abstract}
Aquatic ecosystems of urban rivers are contaminated through waste disposal, which poses a public health problem. The objective of this research was to evaluate the quality of water used for recreation and public supply of six rivers in the city of Cascavel - Paraná, including Cascavel, Quati, Bezerra, Antas, Clarito and Amambay. Samples were collected every 4 months in 2017, and their physicochemical and microbiological parameters, as well as resistance profiles of strains of Escherichia coli to antimicrobials distributed by pharmacies of the primary healthcare network, were evaluated. Parameters such as water temperature, turbidity, total nitrogen, total phosphorus, total coliforms and thermotolerant coliforms showed significant differences. The allowed limit for thermotolerant coliforms, which was set by National Environment Council, Resolution 357/2005, was exceeded in all of the six analyzed rivers. It was determined that $48.1 \%$ of $E$. coli strains showed resistance to nine antimicrobial tested. The highest levels of resistance were found for ampicillin (27.7\%), tetracycline (27.7\%) and amoxicillin (24.0\%). The results of this study contribute to the understanding of the hazards associated with the contamination of springs in urban centers with wastewater containing resistant bacteria. Therefore, recovery work is necessary in these areas because of the importance of these water sources for the entire western region of Paraná state.
\end{abstract}

Keywords: antimicrobial, bacteria, coliforms, contamination, sewage.

\section{Qualidade físico-química e perfis de resistência de Escherichia coli em águas superficiais urbanas}

\section{Resumo}

Os ecossistemas aquáticos dos rios urbanos são contaminados pela disposição de resíduos, o que representa um problema de saúde pública. Esta pesquisa teve por objetivo avaliar a qualidade das águas utilizadas para recreação e abastecimento público de seis rios da cidade de Cascavel - Paraná, sendo eles: Cascavel, Quati, Bezerra, Antas, Clarito e Amambay. Amostras foram coletadas a cada 4 meses em 2017, e seus parâmetros físico-químicos e microbiológicos, bem como os perfis de resistência das cepas de Escherichia coli aos antimicrobianos distribuídos pelas farmácias da rede básica de saúde, foram avaliados. Parâmetros como temperatura da água, turbidez, nitrogênio total, fósforo total, coliformes totais e coliformes termotolerantes apresentaram diferenças significativas. O limite permitido para coliformes termotolerantes, estabelecido pelo Conselho Nacional do Meio Ambiente, Resolução 357/2005, foi excedido em todos os seis rios analisados. Foi determinado que 48,1\% das cepas de E. coli apresentaram resistência aos nove antimicrobianos testados. Os maiores níveis de resistência foram encontrados para ampicilina $(27,7 \%)$, tetraciclina $(27,7 \%)$ e amoxicilina (24,0\%). Os resultados deste estudo contribuem para a compreensão dos riscos associados à contaminação de nascentes em centros urbanos com efluentes contendo bactérias resistentes. Portanto, o trabalho de recuperação é necessário nessas áreas, devido à importância dessas fontes de água para toda a região oeste do estado do Paraná.

Palavras-chave: antimicrobianos, bactéria, coliformes, contaminação, esgoto. 


\section{Introduction}

Water bodies are essential for all life forms and are also used as drains for human activities (Blume et al., 2010; Akoto et al., 2017). Contamination from domestic, industrial and hospital sewage can decrease water quality and compromise aquatic ecosystems, especially those used for public water supplies and recreation (Bueno-Krawczyk et al., 2015; Rodriguez-Mozaz et al., 2015).

Escherichia coli was discovered by Theodor Escherich in 1885. It is a gram-negative bacillary bacterium, commonly found in the intestines of humans and animals, and is an important indicator of water, soil and food contamination (Wambugu et al., 2015; Osinska et al., 2017). The wide use of antimicrobials in the fight against infectious diseases results in a continuous release of these drugs into waters and soils (Wang et al., 2017). Selective pressure leads to an increase in the number of bacteria resistant to these antimicrobials (Cáceres \& Muniesa, 2016; Chen et al., 2017).

The primary antimicrobials used as therapeutics in humans that cause bacterial resistance in surface waters are penicillins, cephalosporins, sulfonamides and tetracyclines, with the latter two also used in veterinary medicine. However, most of these antimicrobials are not metabolized with in the organisms that they are administered to and are excreted in urine and stool (Hsu et al., 2014; Dinh et al., 2017; Proia et al., 2016).

In the environment, bacterial resistance can be transferred between different genera or species, leading to a spread of resistant microorganisms (Garcia-Armisen et al., 2013). Although studies have shown that surface waters are contaminated with antimicrobial-resistant bacteria
(Yao et al., 2015; Jutkina et al., 2016; Maheshwari et al., 2016), few studies are available in the literature examining the impact of urban water sources (Hsu et al., 2014; Souza et al., 2014; Richards et al., 2016).

This is the first study covering three State Hydrographic Basins and has great relevance for the city of Cascavel, which is a region that is supplied by the waters from these rivers. Thus, the objective of this study was to evaluate the six urban rivers that originate in the municipality of Cascavel, Paraná, with respect to the microbiological quality and physicochemical parameters of the water as well as the susceptibility/resistance profiles of E. coli strains to common antimicrobials distributed by public health.

\section{Material and Methods}

\subsection{Area of study}

This study was carried out in the six main rivers that originate in the urban perimeter of the City of Cascavel, Paraná. The rivers evaluated in this study, which are used for recreation and as public water supplies, belong to three Hydrographic Basins, namely the Rio Cascavel and Rio Quati, which belong to the Iguaçu River Basin; the Rio Bezerra and Rio das Antas, which belong to the Paraná River Basin 3; and the Clarito and Amambay Rivers, which are part of the Piquiri River Basin. Figure 1 shows the geographic location of the studied rivers and their respective points of collection.

The climate of the region is classified as subtropical with a hot summer, or Cfa, according to the Köppen and Geiger classification; the mean temperature is $18.2^{\circ} \mathrm{C}$, and the rainfall is $1,822 \mathrm{~mm} /$ year (Climate-Date.org, 2017).

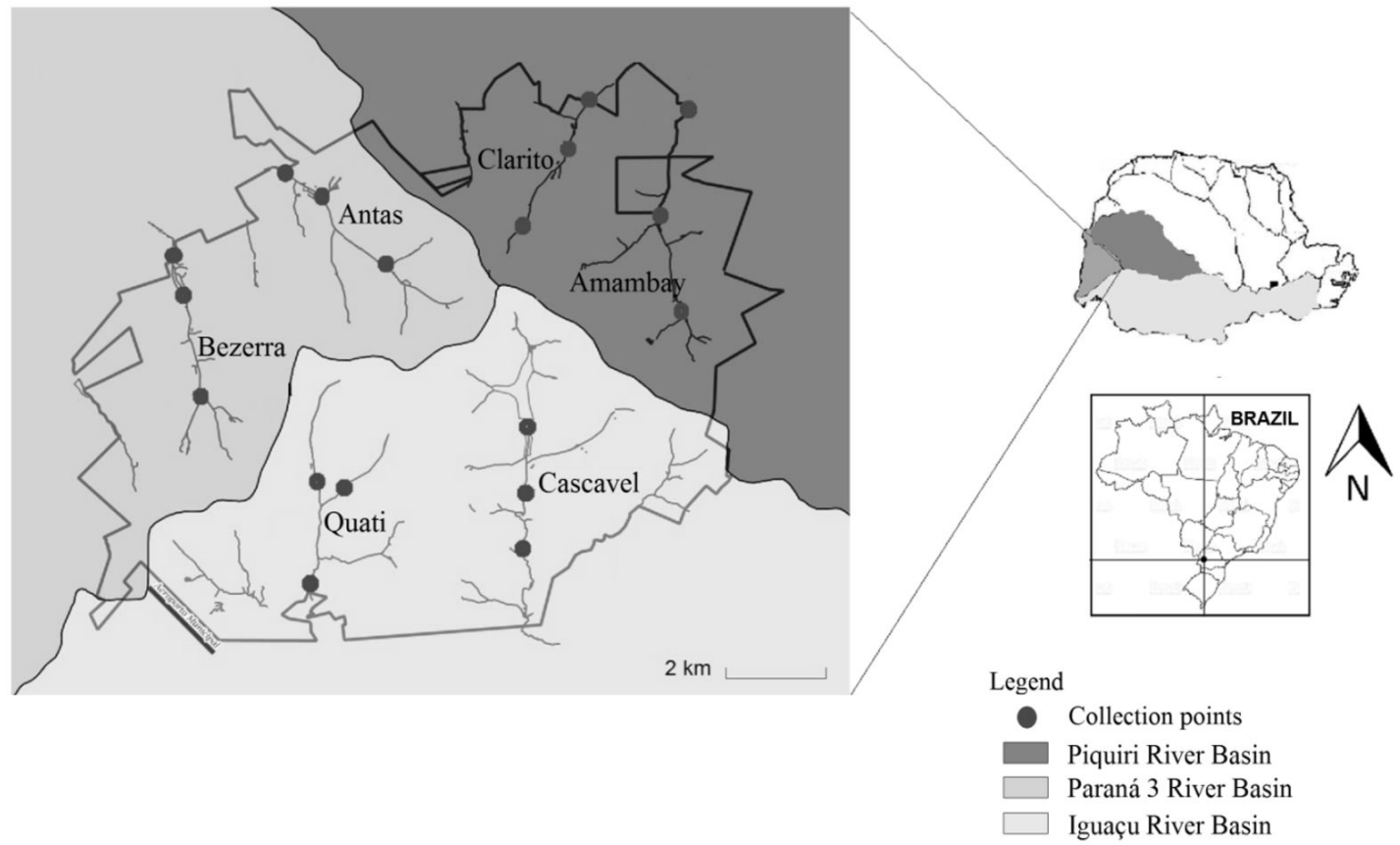

Figure 1. Geographical locations of the rivers and collection points surveyed in the city of Cascavel, PR. 
The city of Cascavel is at an altitude of $781 \mathrm{~m}$ and has an estimated population of 319,608 residents (IBGE, 2017). The abstraction of water used for public supply of the city is carried out by the Companhia de Saneamento do Paraná (Sanitation Company of Parana; SANEPAR), and the water is obtained from River Cascavel.

\subsection{Collection of samples}

The raw water samples were collected superficially and away from the margins according to the National Guide for the Collection and Preservation of Samples, in March, July and November of 2017 (periodicity of every four months). The criterion for choosing these samples was that they be collected in the beginning, middle, and end of the rivers for a more precise evaluation of the possible changes in the water quality of these rivers (composite sample), with 18 samples collected over the study period. The samples were stored and transported in iceboxes and analyzed within the recommended time $(<24 \mathrm{~h})$.

\subsection{Physicochemical analysis}

Parameters such as temperature, $\mathrm{pH}$, turbidity, dissolved oxygen (DO) and total dissolved solids were obtained in the field using a Horiba U-50 multiparameter water quality meter. Total phosphorus $(\mathrm{P})$, total nitrogen $(\mathrm{N})$ and 5-day biochemical oxygen demand (BOD) were analyzed according to the methodology described in the Standard Methods for the Examination of Water and Wastewater (Eaton \& Franson, 2005).

\subsection{Microbiological analyses and isolation of Escherichia coli}

Microbiological analyses for total coliforms (TC) and thermotolerant coliforms (TTC) were performed according to the Most Probable Number (MPN) or multiple tubes methodology described by Silva et al. (1997). After obtaining positive results for coliforms in all of the samples, three strains of $E$. coli were randomly isolated from each river on Eosin-Methylene Blue (EMB) medium, totaling 54 isolates. Afterwards, bacterial colonies were characterized using biochemical tests according to MacFaddin (2000) and Koneman et al. (2008) to evaluate the physiological and metabolic properties of the bacteria.

\subsection{Determination of resistance profiles}

The antimicrobial susceptibility/resistance of $E$. coli was assessed by a disc diffusion technique using Mueller-Hinton agar medium, according to the recommendations of the Clinical and Laboratory Standards Institute (CLSI, 2015), which follow the Kirby-Bauer method (1966). A standard strain of E. coli, ATCC 25922 (American Type Culture Collection), was used as a reference. The results of antibiograms were classified as sensitive, intermediate and resistant according of the file M100-S25 (CLSI, 2015).

The antimicrobials to be tested were chosen based on the data on the distribution of drugs at 37 pharmacies of the primary healthcare network in Cascavel. Thus, nine antimicrobials were selected from seven groups, namely, penicillins [ampicillin $10 \mu \mathrm{g}$ (AMP) and amoxicillin
$10 \mu \mathrm{g}(\mathrm{AMX})]$, macrolides [azithromycin $15 \mu \mathrm{g}$ (AZI)], quinolones [ciprofloxacin $5 \mu \mathrm{g}$ (CIP)], cephalosporins [cefalexin $30 \mu \mathrm{g}(\mathrm{CFL})$ ], aminoglycosides [gentamicin $10 \mu \mathrm{g}(\mathrm{GEN})$ ], tetracyclines [tetracycline $30 \mu \mathrm{g}$ (TET)] and sulfonamides [sulfamethoxazole + trimethoprim $25 \mu \mathrm{g}$ (SXT) and trimethoprim $5 \mu \mathrm{g}$ (TMP)].

\subsection{Water Quality Index (WQI)}

For this evaluation, a modified version of the National Sanitation Foundation (NSF) template was used by the State of Sao Paulo Environmental Company (CETESB), which was based on nine parameters: temperature, DO, TTC, $\mathrm{pH}$, $\mathrm{BOD}$, total nitrogen, total phosphorus, turbidity and total solids (ANA, 2012). The results of the WQI classification, based on the Brazilian Standards, vary in the state of Paraná from excellent (91-100), good (71-91), acceptable (51-70), poor (26-50) to very poor (0-25) (ANA, 2012).

The results of the microbiological and physicochemical analyses were compared with the parameters required by Brazilian National Environment Council (CONAMA) Resolution No. 274/2000 (Brasil, 2000), which defines the criteria for bathing and No. 357/2005 (Brasil, 2005), which defines the classification of water bodies, environmental guidelines, effluent release conditions and standards, with comparisons also made to ordinance No. 2.914/2011 (Brasil, 2011) of the Ministry of Health on the quality of water for human consumption.

\subsection{Statistical analyses}

The data were analyzed using the statistical software RStudio version 0.99 .893 , using analysis of variance followed by Tukey's test. Subsequently, a double factorial analysis was performed using a completely randomized design to evaluate significant differences between the parameters $(\mathrm{p}<0.05)$. Possible correlations between the parameters were evaluated using the Pearson test. Principal component analysis (PCA) was used to identify groupings of related parameters.

\section{Results}

Among the physicochemical and microbiological parameters evaluated, significant differences were observed for water temperature, turbidity, nitrogen, phosphorus, TC and TTC (Table 1). The highest water temperatures were observed for the month of March, and the highest water temperature was recorded in the Cascavel River $\left(23.7^{\circ} \mathrm{C}\right)$. However, the highest $\mathrm{pH}$ and $\mathrm{DO}$ values were observed in November. The nephelometric turbidity units (NTU) recorded for the Cascavel (90.8), Antas (403) and Amambay (137) rivers was due to the rains that occurred prior to collection, although total dissolved solids (TDS) remained within the acceptable values established by CONAMA.

Bacteria from the E. coli group (TC), which are an environmental indicator of water quality, were present in all evaluated rivers. Four of the rivers (Cascavel, Antas, Clarito and Amambay) showed significant numbers of TC. 


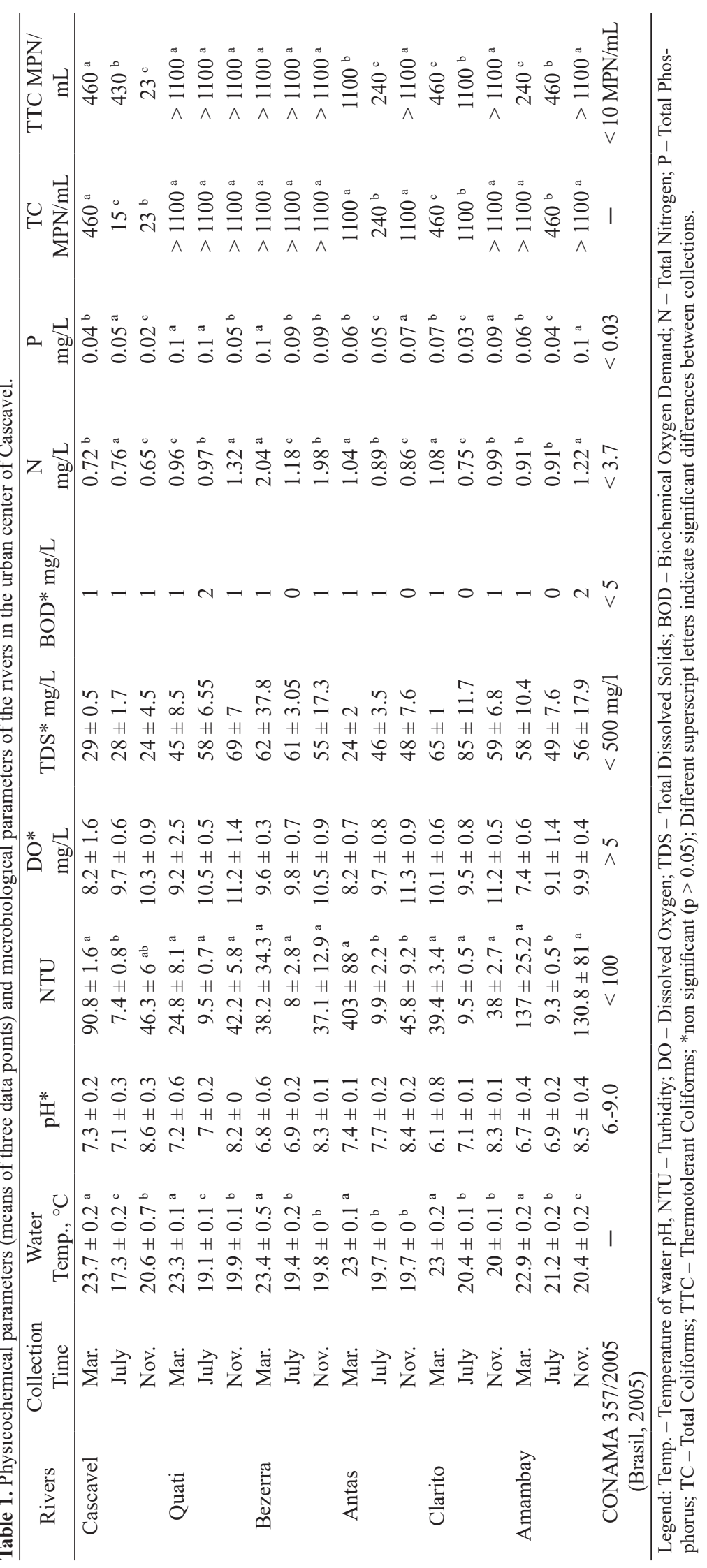




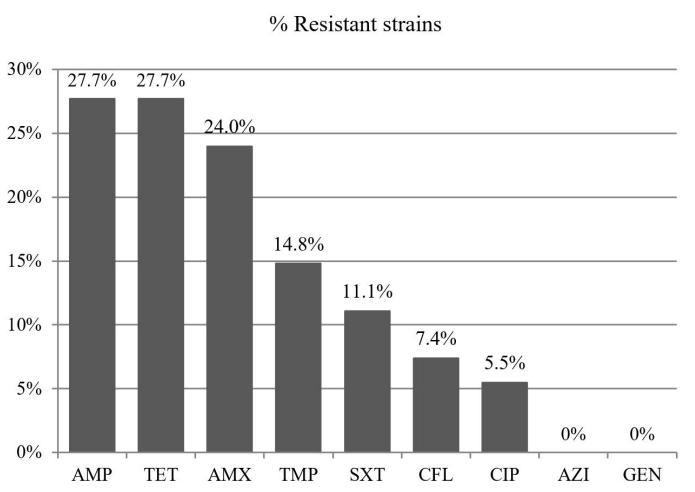

Figure 2. Antimicrobial resistance profiles of $E$. coli strains isolated from rivers in the urban center of the city of Cascavel.

In addition, the TC limit $(<10 \mathrm{MPN} / \mathrm{mL})$ established by CONAMA Resolution 357 was exceeded in all of the rivers.

In general, the evaluations made in the city of Cascavel classify the waters as Poor (44.5\%). However, it should be noted that none of the rivers obtained an Excellent or Good classification based on physicochemical and microbiological parameters. These water quality index (WQI) values are well below the national average, where a classification of Good is observed in $65 \%$ of the collection points (ANA, 2012). Souza et al. (2014) classified the waters of the city of Cascavel as acceptable in their study, revealing a depreciation of water quality since the last WQI analysis.

Among the E. coli isolates, $48.1 \%$ were resistant to antimicrobials, of which $22.2 \%$ were resistant to a single antimicrobial and $25.9 \%$ were multiresistant (resistant to two or more antimicrobials). The highest resistance was observed to the antimicrobials of the penicillin group (AMP and AMX) and TET (Figure 2).

The rivers of the city of Cascavel where E. coli strains showed the highest multiresistance were the Quati River, with multidrug resistance to seven antimicrobials (AMP, AMX, TET, CIP, CFL, SXT and TMP), and Amambay, with multidrug resistance to five (AMP, AMX, TET, SXT and TMP) of the nine antimicrobials tested. The antimicrobials to which the bacteria showed higher resistance were those most used, such as AMP, AMX and TET, which are widely distributed by the pharmacies of the primary healthcare network.

\section{Discussion}

The temperature of the waters varied due to climatic factors such as seasonality, with higher temperatures observed during the summer. The same characteristics were observed by Peres et al. (2010) and Passig et al. (2015). The water temperature varied according to climatic factors, such as seasonality, and was lower in winter months; the same characteristics were found by Peres et al. (2010). According to the data from the Sistema Meteorológico do Paraná (Meteorological System of Paraná), October is the month with the highest rainfall index in Cascavel, which may have resulted in the high water turbidity observed in November. High turbidity tends to decrease the oxygen concentration in the water because of the presence of suspended solids and particles (Graham et al., 2011). Thus, Pearson's correlation showed an inverse correlation between turbidity and DO $(r=-0.49)$.

Although the TC and TTC indexes were variable during the year, there were no significant relationships with the rainfall and temperature. The data obtained in this study in the city of Cascavel suggest anthropogenic interference with water quality, probably caused by the disposal of domestic sewage (Rodriguez-Mozaz et al., 2015); the presence of coliforms in all samples was also reported by Carvalho et al. (2015) for the Campo River basin.

Based on the recommendations by the NSF and CETESB for WQI, among the six assessed rivers, only the Cascavel River maintained the same index (acceptable) for the three assessments; the other indexes ranged from acceptable to poor. For the collections made in November, the waters of the Quati, Bezerra, Antas, Clarito and Amambay rivers were classified as poor.

It was confirmed that several factors could contribute to a low WQI, such as a high demographic density in the regions of the microbasins, low flow rates of the water bodies and the disposal of domestic sewage. However, TTC was the main component that contributed to the low quality indexes. The higher numbers of TTC during November corroborated the worst WQIs.

The high resistance of $E$. coli isolates to TET observed in Cascavel was similar to that observed in Lake Honghu in China, which was due to a high level of consumption, low cost, high effectiveness and low toxicity of the antibiotic (Wang et al., 2017). Resistance to TET has increased throughout decades of TET use for medical treatments; the indiscriminate use of antimicrobials generates a selective pressure on $E$. coli, leading to the selection of resistant strains (Reinthaler et al., 2003, Tenover, 2006).

The resistance profile of $E$. coli isolated from the rivers of the city of Cascavel for specific antimicrobials, such as AMP, AMX, TET, COT and TMP, were observed to have already reached levels of possible substitutions due to the low efficacy on the strains tested. When the resistance of bacteria to a given antimicrobial reaches a level of 10 to $20 \%$, the use of a more effective antimicrobial agent should be considered (Esmerino, 2016). In a study by Souza et al. (2014), which was also performed in Cascavel, the presence of antimicrobial-resistant E. coli was observed; however, the authors did not report any antimicrobial substitution. Thus, it is clear that an increase in the levels of antimicrobial resistance occurred in the city of Cascavel over the last 5 years.

In PCA, which is used to find associations between variables, the first principal component (PC1) explained $28 \%$ of the variance and revealed that TTC and total phosphorus $(\mathrm{P})$ were the main positively contributing factors, which demonstrated a positive and significant correlation (Figure 3). The presence of these factors in surface waters 

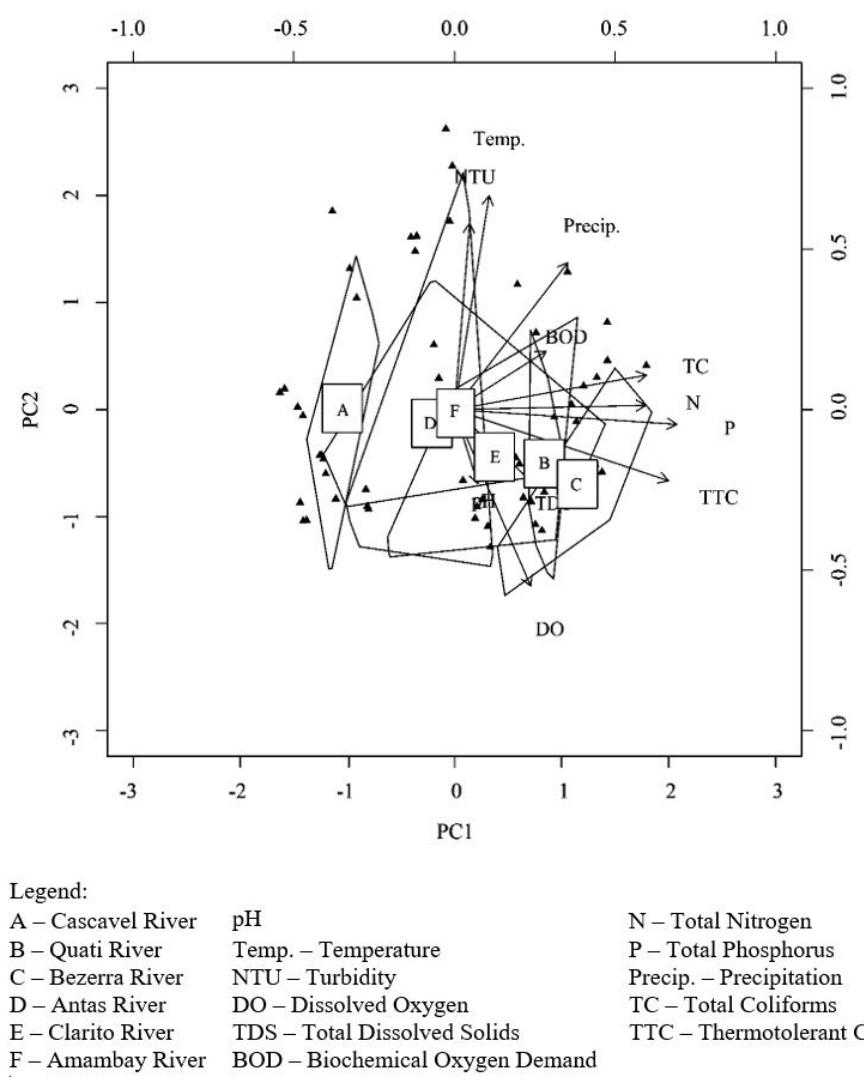

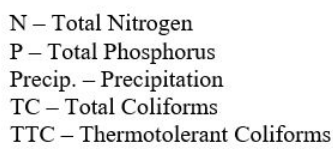

Figure 3. Principal component analysis (PCA) plot, based on physicochemical and microbiological variables among the rivers evaluated in the city of Cascavel.

indicates contamination with wastewater, domestic sewage and human and animal waste (Olaniran et al., 2009). In a study by Bortoletto et al. (2015), the PCA data were also influenced by a high TTC level.

The second principal component (PC2) explained $21 \%$ of the total variance, with water temperature and turbidity being the main positively contributing factors and DO being the main negatively contributing factor, for which we found an inverse correlation equal to $r=-0.6$. The inverse correlation between the water temperature and the amount of DO follows the law proposed by Henry in 1802 , i.e., the lower the temperature of a liquid, the greater the solubility of a gas.

The Cascavel River (A) was the only river for which few principal components were shared with the other rivers; it contained lower numbers of coliforms, and its physicochemical parameters were within the limits set by the Resolutions, as reported by Peres et al. (2010) and Souza et al. (2014). In addition, in this study, the Cascavel River was characterized by the lowest $E$. coli resistance and multiresistance to antimicrobials. This finding is because the region takes special care of the river because its water is used for public supply; the city has a lake and a zoo, which are its symbols, and there is a smaller number of residences on the banks of the river compared with those on the banks of the other rivers.

We observed that the rivers shared the same parameters and were grouped by PCA, i.e., although their microbasins have different characteristics, the rivers responded in similar ways. According to their physicochemical and microbiological parameters, PCA demonstrated that Quati (B) and Bezerra (C) were the most deplorable rivers, owing to high levels of contamination with domestic sewage, which leads to high numbers of coliforms and high levels of nitrogen and phosphorus.

Finally, the physicochemical parameters were correlated with TC and TTC concentrations; however, comparison among the three sets of data using the Pearson test showed no significant relationships.

\section{Conclusions}

1. The physicochemical parameters of water were mostly consistent with the established environmental standards;

2. Total and thermotolerant coliforms were found in all evaluated rivers, making them unsuitable for recreation, primary contact and bathing; 
3. According to the water quality index, the waters of the evaluated rivers were classified below the national average;

4. High multiple drug resistance was found in Escherichia coli isolates from the rivers of Cascavel, which suggests that some of the antimicrobials should be replaced;

5. The rivers studied showed signs of extreme pollution. Therefore, recovery work is needed in these areas because of the importance of these water sources for the entire western region of Paraná state.

\section{Acknowledgements}

This study was financially supported by the Brazilian Federal Agency for the Support and Evaluation of Graduate Education (CAPES) and by the National Council for Scientific and Technological Development (CNPQ).

\section{References}

AGÊNCIA NACIONAL DE ÁGUAS - ANA, 2012 [viewed 1 July 2017]. Panorama da qualidade das águas superficiais no Brasil 2012 [online]. Brasília: ANA. Available from: http:// arquivos.ana.gov.br/institucional/sge/CEDOC/Catalogo/2012/ PanoramaAguasSuperficiaisPortugues.pdf

AKOTO, O., GYAMFI, O., DARKO, G. and BARNES, V.R., 2017. Changes in water quality in the Owabi water treatment plant in Ghana. Applied Water Science, vol. 7, no. 1, pp. 175-186. http://dx.doi.org/10.1007/s13201-014-0232-4.

BLUME, K.K., MACEDO, J.C., MENEGUZZI, A., SILVA, L.B., QUEVEDO, D.M. and RODRIGUES, M.A.S., 2010. Water quality assessment of the Sinos River, Southern Brazil. Brazilian Journal of Biology = Revista Brasileira de Biologia, vol. 70, no. 4, (suppl.), pp. 1185-1193. http://dx.doi.org/10.1590/ S1519-69842010000600008. PMid:21225160.

BORTOLETTO, E.C., SILVA, H.A., BONIFÁCIO, C.M. and TAVARES, C.R.G., 2015. Water quality monitoring of the Pirapó River watershed, Paraná, Brazil. Brazilian Journal of Biology = Revista Brasileira de Biologia, vol. 75, no. 4, suppl. 2, pp. S148-S157. http://dx.doi.org/10.1590/1519-6984.00313suppl. PMid:26815943.

BRASIL. Ministério do Meio Ambiente. Conselho Nacional do Meio Ambiente, 2000 [viewed 10 June 2017]. Resolução CONAMA $n^{\circ} 274$, de 29 de novembro de 2000 [online]. Diário Oficial da República Federativa do Brasil, Brasília. Available from: http:// www.mma.gov.br/port/conama/legiabre.cfm?codlegi $=272$

BRASIL. Ministério do Meio Ambiente. Conselho Nacional do Meio Ambiente, 2005 [viewed 10 June 2017]. Resolução CONAMA $n^{\circ}$ 357, 17 de março de 2005. Dispõe sobre a classificação dos corpos de água e diretrizes ambientais para o seu enquadramento, bem como estabelece as condições e padrões de lançamento de efluentes, e dá outras providências. [online]. Diário Oficial da República Federativa do Brasil, Brasília. Available from: http:// www.mma.gov.br/port/conama/legiabre.cfm?codlegi $=459$

BRASIL. Ministério da Saúde. Secretaria de Vigilância em Saúde. Coordenação-Geral de Vigilância em Saúde Ambiental, 2011 [viewed 10 June 2017]. Portaria Ministério da Saúde nº 2.914, de 12 de dezembro de 2011. Dispõe sobre os procedimentos de controle e de vigilância da qualidade da água para consumo humano e seu padrão de potabilidade. [online]. Diário Oficial da República Federativa do Brasil, Brasília. Available from: http://bvsms. saude.gov.br/bvs/saudelegis/gm/2011/prt2914_12_12_2011.html

BUENO-KRAWCZYK, A.C.D., GUILOSKI, I.C., PIANCINI, L.D.S., AZEVEDO, J.C., RAMSDORF, W.A., IDE, A.H., GUIMARÃES, A.T.B., CESTARI, M.M. and ASSIS, H.C.S., 2015. Multibiomarker in fish to evaluate a river used to water public supply. Chemosphere, vol. 135, pp. 257-264. http://dx.doi. org/10.1016/j.chemosphere.2015.04.064. PMid:25965005.

CÁCERES, W.C. and MUNIESA, M., 2016. Persistence of naturally occurring antibiotic resistance genes in the bacteria and bacteriophage fractions of wastewater. Water Research, vol. 95, pp. 11-18. http://dx.doi.org/10.1016/j.watres.2016.03.006. PMid: 26978717.

CARVALHO, K.Q., LIMA, S.B., PASSIG, F.H., GUSMÃO, L.K., SOUZA, D.C., KREUTZ, C., BELINI, A.D. and ARANTES, E.J., 2015. Influence of urban area on the water quality of the Campo River basin, Paraná State, Brazil. Brazilian Journal of Biology = Revista Brasileira de Biologia, vol. 75, no. 4, suppl. 2, pp. S96-S106. http://dx.doi.org/10.1590/1519-6984.00413suppl. PMid:26628235.

CHEN, Q., LI, H., ZHOU, X., ZHAO, Y., SU, J., ZHANG, X. and HUANG, F., 2017. An underappreciated hotspot of antibiotic resistance. The groundwater near the municipal solid waste land fi 11. The Science of the Total Environment, vol. 609, pp. 966-973. http://dx.doi.org/10.1016/j.scitotenv.2017.07.164. PMid:28783909.

CLIMATE-DATE.org, 2017 [viewed 5 September 2017]. Dados climáticos para cidades mundiais [online]. Available from: https:// pt.climate-data.org/location/5965/

CLINICAL AND LABORATORY STANDARDS INSTITUTE - CLSI, 2015 [viewed 10 January 2017]. Performance standards for antimicrobial susceptibility testing [online]. Wayne: CLSI. Twenty-Fifth Informational Supplement. CLSI document M100-S25. Available from: https://clsi.org/standards/products/microbiology/

DINH, Q.T., MOREAU-GUIGON, E., LABADIE, P., ALLIOT, F., TEIL, M.-J., BLANCHARD, M., EURIN, J. and CHEVREUIL, M., 2017. Fate of antibiotics from hospital and domestic sources in a sewage network. The Science of the Total Environment, vol. 575, pp. 758-766. http://dx.doi.org/10.1016/j. scitotenv.2016.09.118. PMid:27693143.

EATON, A.D. and FRANSON, M.A.H. 2005. Standard methods for the examination of water and wastewater. 21 th ed. Washington: APHA - American Public Health Association.

ESMERINO, A.L., 2016. Diversidade microbiológica e suscetibilidade em cepas de Escherichia coli uropatogênica diagnosticadas em Ponta Grossa, Paraná. Revista Brasileira de Análies Clínicas, vol. 48, no. 3, pp. 48-54.

GARCIA-ARMISEN, T., ANZIL, A., CORNELIS, P., CHEVREUIL, M. and SERVAIS, P, 2013. Identification of antimicrobial resistant bacteria in rivers: insights into the cultivation bias. Water Research, vol. 47, no. 14, pp. 4938-4947. http://dx.doi. org/10.1016/j.watres.2013.05.036. PMid:23863386.

GRAHAM, D.W., RIEUMONT, S.O., KNAPP, C.W., LIMA, L., WERNER, D. and BOWEN, E., 2011. Antibiotic resistance gene abundances associated with waste discharges to the almendares River near Havana, Cuba. Environment Science Technology, vol. 45, pp. 418-424. http://dx.doi.org/10.1021/es102473z. PMid: 21133405 . 
HSU, J.T., CHEN, C.Y., YOUNG, C.W., CHAO, W.L., LI, M.H., LIU, Y.H., LIN, C.M. and YING, C., 2014. Prevalence of sulfonamide-resistant bacteria, resistance genes and integronassociated horizontal gene transfer in natural water bodies and soils adjacent to a swine feedlot in northern Taiwan. Journal of Hazardous Materials, vol. 277, pp. 34-43. http://dx.doi. org/10.1016/j.jhazmat.2014.02.016. PMid:24637153.

INSTITUTO BRASILEIRO DE GEOGRAFIA E ESTATÍSTICA - IBGE, 2017. Cidades. Rio de Janeiro: IBGE, vol. 2017, pp. 30.

JUTKINA, J., RUTGERSSON, C., FLACH, C.-F. and JOAKIM LARSSON, D.G., 2016. An assay for determining minimal concentrations of antibiotics that drive horizontal transfer of resistance. The Science of the Total Environment, vol. 548-549, pp. 131-138. http://dx.doi.org/10.1016/j.scitotenv.2016.01.044. PMid:26802341.

KONEMAN, E.W., ALLEN, S.D. and JANDA, W.M., 2008. Diagnóstico microbiológico: texto e atlas colorido. 6 . ed. Rio de Janeiro: MEDSI, $1760 \mathrm{p}$.

MACFADDIN, J.F., 2000. Biochemical tests for identifications of medical bacteria. 3rd ed. Philadelphia: Lippincott Williams \& Wilkins, 912 p.

MAHESHWARI, M., YASER, N.H., NAZ, S., FATIMA, M. and AHMAD, I., 2016. Emergence of ciprofloxacin-resistant extended-spectrum $\beta$-lactamase-producing enteric bacteria in hospital wastewater and clinical sources. Journal of Global Antimicrobial Resistance, vol. 5, pp. 22-25. http://dx.doi. org/10.1016/j.jgar.2016.01.008. PMid:27436461.

OLANIRAN, A.O., NAICKER, K. and PILLAY, B., 2009. Antibiotic resistance profiles of Escherichia coli isolates from river sources in Durban, South Africa. World Journal of Microbiology \& Biotechnology, vol. 25, no. 10, pp. 1743-1749. http://dx.doi. org/10.1007/s11274-009-0071-x.

OSINSKA, A., KORZENIEWSKA, E., HARNISZ, M. and NIESTEPSKI, S., 2017. The prevalence and characterization of antibiotic-resistant and virulent Escherichia coli strains in the municipal wastewater system and their environmental fate. The Science of the Total Environment, vol. 577, pp. 367-375. http:// dx.doi.org/10.1016/j.scitotenv.2016.10.203. PMid:27816226.

PASSIG, F.H., LIMA, S.B., CARVALHO, K.Q., HALMEMAN, M.C.R., SOUZA, P.C. and GUSMÃO, L.K., 2015. Monitoring of urban and rural basins: water quality of Mourão basin. Brazilian Journal of Biology = Revista Brasileira de Biologia, vol. 75, no. 4, suppl. 2, pp. 158-164. http://dx.doi.org/10.1590/15196984.01213suppl. PMid:26628221.

PERES, C.K., BRANCO, C.C.Z., KRUPEK, R.A. and ROCHA, J.C., 2010. Longitudinal distribution and seasonality of macroalgae in a subtropical stream impacted by organic pollution. Acta Limnologica Brasiliensia, vol. 22, no. 2, pp. 199-207. http:// dx.doi.org/10.1590/S2179-975X2010000200009.

PROIA, L., VON SCHILLER, D., SANCHEZ-MELSIÓ, A., SABATER, S., BORREGO, C.M., RODRÍGUEZ-MOZAZ,
S. and BALCÁZAR, J.L., 2016. Occurrence and persistence of antibiotic resistance genes in river biofilms after wastewater inputs in small rivers. Environmental Pollution, vol. 210, pp. 121-128. http://dx.doi.org/10.1016/j.envpol.2015.11.035. PMid:26708766.

REINTHALER, F.F., POSCH, J., FEIERL, G., WÜST, G., HAAS, D., RUCKENBAUER, G., MASCHER, F. and MARTH, E., 2003. Antibiotic resistance of $E$. coli in sewage and sludge. Water Research, vol. 37, no. 8, pp. 1685-1690. http://dx.doi. org/10.1016/S0043-1354(02)00569-9. PMid:12697213.

RICHARDS, S., WITHERS, P.J.A., PATERSON, E., MCROBERTS, C.W. and STUTTER, M., 2016. Temporal variability in domestic point source discharges and their associated impact on receiving waters. The Science of the Total Environment, vol. 571, pp. 1275-1283. http://dx.doi.org/10.1016/j.scitotenv.2016.07.166. PMid:27474989.

RODRIGUEZ-MOZAZ, S., CHAMORRO, S., MARTI, E., HUERTA, B., GROS, M., SÀNCHEZ-MELSIÓ, A., BORREGO, C.M., BARCELÓ, D. and BALCÁZAR, J.L., 2015. Occurrence of antibiotics and antibiotic resistance genes in hospital and urban wastewaters and their impact on the receiving river. Water Research, vol. 69, pp. 234-242. http://dx.doi.org/10.1016/j. watres.2014.11.021. PMid:25482914.

SILVA, N., SILVEIRA, N.F.A. and JUNQUEIRA, V.C.A., 1997. Manual de métodos de análise microbiológica de alimentos. São Paulo: Varela, 295 p.

SOUZA, M., PINTO, F.G.S., FRUET, T.K., PIANA, P.A. and MOURA, A.C., 2014. Quality indicators for environmental and resistance profile of Escherichia coli strains isolated in Rio Cascavel, Paraná, Brazil. Engenharia Agrícola, vol. 34, no. 2, pp. 352-362. http://dx.doi.org/10.1590/S0100-69162014000200016.

TENOVER, F.C., 2006. Mechanisms of Antimicrobial Resistance in Bacteria. The American Journal of Medicine, vol. 119, no. 6, suppl. 1, pp. S3-S10, discussion S62-S70. http://dx.doi.org/10.1016/j. amjmed.2006.03.011. PMid:16735149.

WAMBUGU, P., HABTU, M., IMPWI, P., MATIRU, V. and KIIRU, J., 2015. Antimicrobial Susceptibility Profiles among Escherichia coli Strains Isolated from Athi River Water in Machakos County, Kenya. Advances in Microbiology, vol. 5, no. 10, pp. 711-719. http://dx.doi.org/10.4236/aim.2015.510074.

WANG, Z., DU, Y., YANG, C., LIU, X., ZHANG, J., LI, E., ZHANG, Q. and WANG, X., 2017. Occurrence and ecological hazard assessment of selected antibiotics in the surface waters in and around Lake Honghu, China. The Science of the Total Environment, vol. 609, pp. 1423-1432. http://dx.doi.org/10.1016/j. scitotenv.2017.08.009. PMid:28800685.

YAO, L., WANG, Y., TONG, L., LI, Y., DENG, Y., GUO, W. and GAN, Y., 2015. Seasonal variation of antibiotics concentration in the aquatic environment : a case study at Jianghan Plain, central China. The Science of the Total Environment, vol. 527-528, pp. 56-64. http://dx.doi.org/10.1016/j.scitotenv.2015.04.091. PMid:25956148. 